\title{
Alteration of the Wnt/GSK3 $\beta / \beta$-catenin signalling pathway by rapamycin ameliorates pathology in an Alzheimer's disease model
}

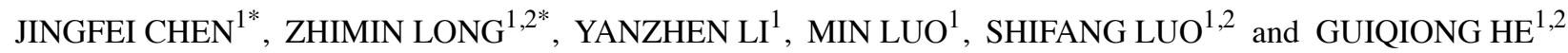 \\ ${ }^{1}$ Institute of Neuroscience, ${ }^{2}$ Department of Anatomy, Chongqing Medical University, Chongqing 400016, P.R. China
}

Received October 4, 2018; Accepted April 12, 2019

DOI: $10.3892 /$ ijmm.2019.4198

\begin{abstract}
The abnormal activation of glycogen synthase kinase $3 \beta(\mathrm{GSK} 3 \beta)$ is one of the mechanisms involved in the pathogenesis of Alzheimer's disease (AD), which results in amyloid $\beta$-peptide $(A \beta)$ plaque overproduction, Tau hyperphosphorylation and neuronal loss. A number of studies have reported that the activation of the mammalian target of rapamycin (mTOR) contributes to the generation and deposition of $A \beta$, as well as to the formation of neurofibrillary tangles (NFTs) by inhibiting autophagy. GSK3 $\beta$ is also involved in the mTOR signalling pathway. However, whether the inhibition of the activation of $\mathrm{mTOR}$ via the regulation of the function of GSK3 $\beta$ affects the pathology of AD remains unclear. In this study, we intraperitoneally injected amyloid precursor protein (APP)/presenilin-1 (PS1) transgenic mice with rapamycin, a known activator of autophagy that inhibits mTOR. Our results revealed that rapamycin treatment decreased senile plaque deposition by reducing APP generation, and downregulating $\beta$ - and $\gamma$-secretase activity. Rapamycin also increased $\mathrm{A} \beta$ clearance by promoting autophagy and reduced Tau hyperphosphorylation by upregulating the levels of insulin-degrading enzyme. Additionally, rapamycin markedly promoted the proliferation of differentiated SH-SY5Y cells stably transfected with the APPswe gene and prevented neuronal loss in the brains of mice in a model of AD. Moreover, rapamycin induced autophagy and promoted autolysosome degradation. In this study, we provide evidence that rapamycin inhibits GSK $3 \beta$ activation and elevates $\beta$-catenin expression by improving the Wnt3a expression levels, which facilitates the amelioration of AD pathology. On the whole, our findings indicate that rapamycin inhibits
\end{abstract}

Correspondence to: Professor Guiqiong He or Professor Shifang Luo, Institute of Neuroscience, Chongqing Medical University, 1 Yi Xue Yuan Road, Yuzhong, Chongqing 400016, P.R. China

E-mail: guiqionghe@cqmu.edu.cn

E-mail: luoshifang@126.com

*Contributed equally

Key words: Alzheimer's disease, rapamycin, glycogen synthase kinase $3 \beta$, autophagy, amyloid $\beta$-peptide the activation of mTOR and alters the Wnt/GSK3 $\beta / \beta$-catenin signalling pathway; thus, it may serve as a therapeutic target in the treatment of $\mathrm{AD}$.

\section{Introduction}

Alzheimer's disease (AD) is a progressive, irreversible neurodegenerative disease and is characterized by neuronal loss, neurofibrillary tangles (NFTs) of hyperphosphorylated Tau and amyloid $\beta$-peptide $(A \beta)$ protein accumulation $(1,2)$. Progressive synapse loss and cell death, particularly in the frontal cortex and the hippocampus region, is characteristic of AD and eventually leads to severe memory loss. The progressive accumulation of $A \beta$ peptides and Tau hyperphosphorylation can enhance the assembly of NFTs and the formation of senile plaques (SPs); the latter exert additional toxic effects on neuronal function and cognitive function $(3,4)$.

In recent years, a number of studies have found that glycogen synthase kinase $3 \beta$ (GSK $3 \beta$ ) is a key modulator of the pathogenesis of AD. It has been demonstrated that GSK $3 \beta$ contributes to $A \beta$-induced neuronal toxicity, and $A \beta$ production and accumulation is promoted by GSK $3 \beta$ activators and is reduced by GSK3 $\beta$ inhibitors (5-8). Additionally, the overexpression of GSK $3 \beta$ increases Tau hyperphosphorylation $(9,10)$, and the inhibition of GSK3 $\beta$ activity reduces Tau hyperphosphorylation, restores spatial memory deficits, and decreases neuronal cell death (11). GSK3 $\beta$ is also a pivotal regulator of the Wnt/ $\beta$-catenin signalling pathway, which is closely related to the pathogenesis of $\operatorname{AD}(12,13)$.

Increasing evidence has indicated that the activation of mammalian target of rapamycin (mTOR) signalling contributes to the progression of AD and eventually exacerbates AD pathology and clinical manifestation $(14,15)$. Therefore, mTOR inhibitors may be effective drugs for the treatment of AD (16). GSK3 $\beta$ is also involved in the mTOR signalling pathway. However, it remains unclear as to whether the inhibition of the activation of mTOR via the regulation of the function of GSK $3 \beta$ can prevent the progression of $A D$. In this study, we found that GSK3 $\beta$ activity was inhibited following treatment with rapamycin, which decreased $A \beta$ deposition and increased Tau clearance. The data of this study suggest that rapamycin can attenuate the development of AD by activating the Wnt pathway and inhibiting GSK $3 \beta$, in addition to inducing autophagy, thus providing a novel target for AD therapy. 


\section{Materials and methods}

Mice and drug treatment. A total of 20 4-month-old amyloid precursor protein $(A P P) /$ presenilin-1 ( $P S 1)$ double-transgenic mice overexpressing mouse/human APP $(\mathrm{Mo} / \mathrm{Hu} A \beta$ PP695swe) and mutant human PS1- 49 , weighing 22-25 g, were purchased from Beijing HFK Bioscience Co. Ltd. Mice were housed in individually ventilated cage (IVC) systems in a 12-h light/dark cycle, with free access to water and food. All procedures involving animals were performed under institutional guidelines. This study was approved by The Ethics Committee of Chongqing Medical University (SCXK 2014-0004). Ten male mice were randomly divided into the rapamycin group and the control group, 5 mice per group. The mice in the rapamycin group were treated with rapamycin at $2 \mathrm{mg} / \mathrm{kg}$ per day for 4 weeks, while the mice in the control group were administered the same volume of the solvent as the rapamycin group. Rapamycin (Gene Operation, Ann Arbor, MI, USA) was first dissolved in dimethyl sulfoxide (DMSO) and then diluted with double deionized water containing 5\% Tween-80 and 5\% PEG 400 immediately prior to intragastric administration. The body weight of the mice was recorded.

Routine blood analysis and chemical detection. Drug safety was evaluated by aroutine blood examination and chemical detection. Blood was obtained from the lateral caudal vein of the mice (approximately $200 \mu \mathrm{l}$ per time). The supernatants of the blood samples obtained by centrifugation $(1,500 \mathrm{x} \mathrm{g}$ for $15 \mathrm{~min}$ ) were kept at room temperature for $1 \mathrm{~h}$ and were then collected for chemical testing, including the quantification of alanine aminotransferase (ALT), aspartate aminotransferase (AST), blood urea nitrogen (BUN), triglyceride (TG), serum creatinine (Scr) and total bilirubin (TBIL). Routine blood tests consisted of a red blood cell (RBC) count, mean corpuscular volume (MCV), white blood cell (WBC) count, haemoglobin (HGB), mean platelet volume (MPV) and a platelet (PLT) count.

Brain tissue preparation. Mice were intraperitoneally injected with $10 \%$ chloral hydrate $(400 \mathrm{mg} / \mathrm{kg})$ and sacrificed by carbon dioxide $\left(\mathrm{CO}_{2}\right)$ euthanasia $\left(\mathrm{CO}_{2}\right.$ percentage volume displacement is $20 \% / \mathrm{min}$ ). For each mouse, half of the brain was used for protein extraction, and the other half was post-fixed in cold $4 \%$ paraformaldehyde (PFA) in $0.1 \mathrm{M}$ phosphate-buffered saline (PBS) for $24 \mathrm{~h}$. Following dehydration and embedding with optimal cutting temperature (OCT) compound (Sakura Finetek USA, Inc., Torrance, CA, USA), the fixed brain tissues were cut into $10-\mu \mathrm{m}$-thick coronal sections using a microtome (Leica Microsystems, Wetzlar Germany).

$4 G 8$ staining and thioflavin $S$ staining. The slides were developed with methanoic acid for $10 \mathrm{~min}$ at room temperature before being blocked in $0.1 \%$ Triton and 5\% BSA. The sections were then incubated at $4^{\circ} \mathrm{C}$ with mouse anti-A $\beta, 17-24$ (4G8) antibody (800704; 1:250; BioLegend, San Diego, CA, USA) overnight. After washing, the slides were incubated at $37^{\circ} \mathrm{C}$ for 40 min with cy3-conjugated goat anti-mouse antibody (A0521; 1:200; Beyotime Biotechnology, Haimen, China). The mounted slides were observed using a TCS-TIV confocal laser scanning microscope (Leica Microsystems).
The slides were deparaffinised with clearing acetone for $15 \mathrm{~min}$ and hydrated by a series of graded ethanol (EtOH) solutions as follows: $100-80-70 \%$. The sections were then washed with double distilled water followed by $0.1 \%$ potassium permanganate solution. The slides were subsequently incubated in filtered $1 \%$ aqueous thioflavin-S (1326-12-1; Sigma-Aldrich, Darmstadt, Germany) for $15 \mathrm{~min}$ at room temperature in the dark. The slides were then washed in a series of graded EtOH solutions of 80-70\% and then washed 3 times with distilled water. The coverslip was mounted with aqueous mounting media, and the samples were observed under a TCS-TIV confocal laser scanning microscope (Leica Microsystems).

We counted senile plaques in half of the brains of the mice, including the whole cortex and hippocampus on each slice, and 3 mice in each group. All counts are made by the same individual who was blinded to the experimental conditions.

Cells, cell culture and treatment. Differentiated SH-SY5Y cells stably transfected with the APPsw gene (gift from the Laboratory of Translational Medical Research in Cognitive Development and Learning and Memory Disorders, Children's Hospital of Chongqing Medical University, Chongqing, China) were confirmed to be human through STR profiling. Cells were cultured in DMEM (Gibco/Thermo Fisher Scientific, Waltham, MA, USA) at $37^{\circ} \mathrm{C}$ with $5 \% \mathrm{CO}_{2}$ and $95 \%$ air (v/v) supplemented with $10 \%$ foetal bovine serum (FBS, Biological Industries, USA), $100 \mathrm{U} / \mathrm{ml}$ penicillin and $100 \mu \mathrm{g} / \mathrm{ml}$ streptomycin. Rapamycin (Gene Operation) was dissolved in DMSO and then diluted in the culture medium. The final concentration of DMSO was $<0.1 \%$. The control group was treated with the same concentration of DMSO. The cells were incubated in 96-well flat-bottom plates $\left(1.0 \times 10^{4}\right.$ cells/well) with 50 or $100 \mathrm{nM}$ rapamycin for $24 \mathrm{~h}$ before cell proliferation was assessed.

Determination of cell proliferation. The cell proliferative ability was determined by a Cell-Light ${ }^{\mathrm{TM}}$ EdU Apollo ${ }^{\circledR} 488$ In Vitro Imaging kit (RiboBio Co., Ltd., Guangzhou, China). Following treatment with 50 and $100 \mathrm{nM}$ rapamycin, the cells were treated with $50 \mu \mathrm{M}$ EdU for $2 \mathrm{~h}$ at $37^{\circ} \mathrm{C}$. The cells were then fixed, permeabilized and exposed to $1 \mathrm{X}$ Apollo $^{\circledR}$ reaction solution for $30 \mathrm{~min}$. The cell nuclei were then counterstained with DAPI. After washing with phosphate-buffered saline (PBS), the samples were examined under a fluorescence microscope (Leica Microsystems). Each experimental condition was repeated in at 6 wells, and data were calculated from 3 independent experiments.

Detection of autophagy by $m R F P-G F P-L C 3$ adenoviral vector. Differentiated SH-SY5Y cells stably transfected with the APPswe gene were plated in 24-well plates and transfected with mRFP-GFP-LC3 adenoviral vectors (Hanbio Biotechnology Co., Ltd. Shanghai, China) at 70-80\% confluence. On the 2nd day following transfection, 50 or $100 \mathrm{nM}$ rapamycin was added to the medium for $24 \mathrm{~h}$. After fixing the cells with PFA, autophagy was observed under a TCS-TIV confocal laser scanning microscope (Leica Microsystems).

Western blot analysis. Tissues from the half brains of 3 mice from each group were lysed in RIPA lyses buffer 
(Pierce/Thermo Fisher Scientific). The protein concentration was determinated by BCA. Subsequently, 10 or $12 \%$ SDS-PAGE gels were used to separate proteins. The proteins were then transferred to polyvinylidene fluoride (PVDF) membranes (Immobilon-P, Millipore, Bedford, MA, USA). Subsequently, the membranes were blocked in 5\% BSA (dissolved in double deionized water). The membranes were incubated with rabbit anti-LC3B antibody (L7543; 1:1,000; Sigma-Aldrich, St. Louis, MO, USA), rabbit anti-NeuN antibody (D4G40), rabbit anti- $\beta$-catenin antibody (D10A8), rabbit anti-p62 antibody (5114) (all 1:1,000; all from Cell Signaling Technology, Danvers, MA, USA), rabbit anti-Beclin 1 antibody (ab62557), mouse anti-Tau5 antibody (ab80579), rabbit antiinsulin degrading enzyme (IDE) antibody (ab133561), rabbit anti-PHF-1 antibody (ab184951), mouse anti-GSK3 $\beta$ antibody (ab93926), rabbit anti-BACE1 antibody (ab2077), rabbit anti-PS1 antibody (ab71181), mouse anti-APP mouse antibody (ab32136) (1:1,000; all purchased from Abcam, Cambridge, MA, USA), anti-phosphorylated GSK3 $\beta$ (1:1,000; sc81495; Santa Cruz Biotechnology, Santa Cruz, CA, USA), mouse biotin anti-A $\beta, 17-24$ antibody $(1: 250 ; 800704$; BioLegend) and mouse anti- $\beta$-actin antibody (1:1,000; ABM0001-50; Zoonbio Biotechnology, Nanjing, China) at $4^{\circ} \mathrm{C}$ overnight. After washing, the membranes were incubated at $37^{\circ} \mathrm{C}$ for 40 min with horseradish peroxidase-conjugated secondary antibody (goat anti-mouse IgG, S0002 or goat anti-rabbit IgG, S0001, Affinity Biosciences, USA) at a 1:5,000 dilution. The membranes were washed again and treated with enhanced chemiluminescence (ECL) substrate (K12045; Advansta, Menlo Park, CA, Cincinnati, OH, USA). The membranes were then visualized with Gel Imaging Systems software and quantified by Quantity One image software (both from Bio-Rad, Hercules, CA, USA).

Statistical analysis. Data were analysed with GraphPad Prism 5.0 software. All results are expressed as the means \pm standard error of the mean (SEM). Statistical comparisons between the control and rapamycin treatment groups were determined using a two-sample t-test or one-way ANOVA, followed by a Bonferroni test. The level of significance was $\mathrm{P}<0.05$.

\section{Results}

Treatment with rapamycin decreases the deposition of senile plaques in APP/PS1 transgenic mice. To assess whether rapamycin treatment results in $A \beta$ aggregation and deposition in the brain, coronal sections of rapamycin- and vehicle-treated mice were immunohistochemically and fluorescently stained for $\mathrm{A} \beta$ plaques using 4G8 antibody and thioflavin $\mathrm{S}$ staining, respectively. The results revealed that rapamycin treatment significantly reduced the number $(6.333 \pm 0.471$ vs. $11.390 \pm 0.964, \mathrm{t}=4.712, \mathrm{P}<0.001)$ and the area of SPs $(12.610 \pm 0.622$ vs. $30.670 \pm 1.193, \mathrm{t}=13.420, \mathrm{P}<0.001)$ in both the hippocampus and cortex of the mouse brains compared with the control treatment. Thioflavin $\mathrm{S}$ staining revealed that the rapamycin group had fewer fibrillary $A \beta$ deposits than the control group (Fig. 1).

Rapamycin decreases A $\beta$ generation. The expression levels of APP, BACE1 and PS1 in the mouse brains were measured by western blot analysis. Rapamycin treatment had no effect on the level of APP $(100.000 \pm 8.173$ vs. $96.220 \pm 12.590, t=0.252$, $\mathrm{P}=0.806)$. However, the APP cleaving enzymes, BACE1 and PS1, were both decreased following treatment with rapamycin $(100.000 \pm 3.900$ vs. $81.150 \pm 2.637, \mathrm{t}=4.005, \mathrm{P}=0.016$; and $100.000 \pm 0.520$ vs. $86.320 \pm 0.766, \mathrm{t}=14.790, \mathrm{P}<0.001$, respectively; Fig. 2).

Rapamycin accelerates the degradation of $A \beta$. The $\mathrm{A} \beta$ levels in the mouse brains were then examined. The results of western blot analysis revealed that the $\mathrm{A} \beta$ level was markedly decreased by rapamycin treatment $(100.000 \pm 4.185$ vs. $68.060 \pm 2.442, \mathrm{t}=6.591, \mathrm{P}=0.003)$ compared with the control group. To examine the possibility that the $A \beta$ reduction induced by rapamycin treatment is associated with $A \beta$ clearance, western blot analysis was used to measure the levels of the $A \beta$ degradation enzyme, IDE, in the mouse brains. The results revealed that IDE expression increased in the rapamycin group compared with the control group (100.000 2.418 vs. 139.900 $\pm 6.851, \mathrm{t}=5.495, \mathrm{P}<0.001$; Fig. 3 ).

Rapamycin decreases the levels of total Tau and abnormal hyperphosphorylated Tau. The anti-Tau antibody, Tau 5, was used to measure the total Tau level. We found that the total Tau level in the rapamycin treatment group was significantly decreased by $10.488 \%$ compared with that in the control group $(100.000 \pm 1.187$ vs. $75.450 \pm 6.672, \mathrm{t}=3.622, \mathrm{P}=0.005)$. In AD-affected brains, the aberrant hyperphosphorylation of Tauinduces the formation of paired helical filaments (PHFs), which contributes to the formation of NFTs (17). In the present study, the PHF-1 levels were decreased by $12.430 \%$ in the rapamycin group compared with the control group (100.000 \pm 3.776 vs. $87.570 \pm 2.320, t=2.805, \mathrm{P}=0.049$; Fig. 4).

Rapamycin increases cell proliferation. The effects of rapamycin on cell proliferation were assessed by an EdU incorporation assay. Quantitative analysis revealed that the number of EdU-incorporated cells was significantly increased by treatment with $50 \mathrm{nM}(43.020 \pm 0.303$ vs. $47.280 \pm 0.831$, $\mathrm{t}=4.943, \mathrm{P}<0.01 ; \mathrm{F}=42.72 ; \mathrm{P}<0.001)$ and $100 \mathrm{nM}(43.020 \pm 0.303$ vs. $50.980 \pm 0.578, \mathrm{t}=9.236, \mathrm{P}<0.001 ; \mathrm{F}=42.72 ; \mathrm{P}<0.001)$ rapamycin (Fig. 5A and $\mathrm{B}$ ). The neuronal nuclei (NeuN) antigen is a neuronal nuclear marker. The results of western blot analysis revealed that rapamycin treatment elevated NeuN expression in the brain tissues compared with the control group $(100.000 \pm 4.618$ vs. $189.600 \pm 4.156, \mathrm{t}=14.420, \mathrm{P}<0.001)$ (Fig. 5C and D).

Rapamycin induces autophagic activities. The treatment of differentiated SH-SY5Y cells stably transfected with the APPswe gene with 50 and $100 \mathrm{nM}$ rapamycin markedly increased the number of mRFP-positive cells $(1.333 \pm 0.882$ vs. $42.670 \pm 3.712, \mathrm{t}=5.369, \mathrm{P}<0.01 ; 1.333 \pm 0.882$ vs. $36.000 \pm 8.622$, $\mathrm{t}=4.503, \mathrm{P}<0.05$, respectively; $\mathrm{F}=16.62, \mathrm{P}=0.004)$ and $100 \mathrm{nM}$ rapamycin treatment also increased the number of GFP-positive puncta $(1.000 \pm 0.577$ vs. $20.330 \pm 5.783, \mathrm{t}=4.028$, $\mathrm{P}<0.05 ; \mathrm{F}=8.270, \mathrm{P}=0.019$; Fig. 6A and $\mathrm{B})$. Rapamycin treatment at $50 \mathrm{nM}$ increased the number of autolysosomes $(0.333 \pm 0.333$ vs. $34.330 \pm 2.963, \mathrm{t}=9.016, \mathrm{P}<0.001 ; \mathrm{F}=40.770$, $\mathrm{P}<0.001$ ), and $100 \mathrm{nM}$ treatment increased the number of 
A

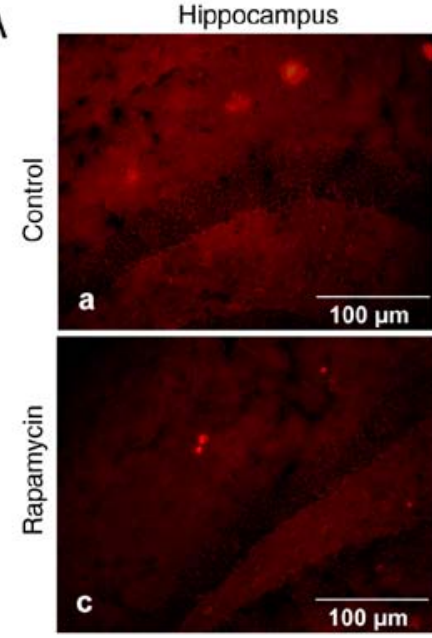

B

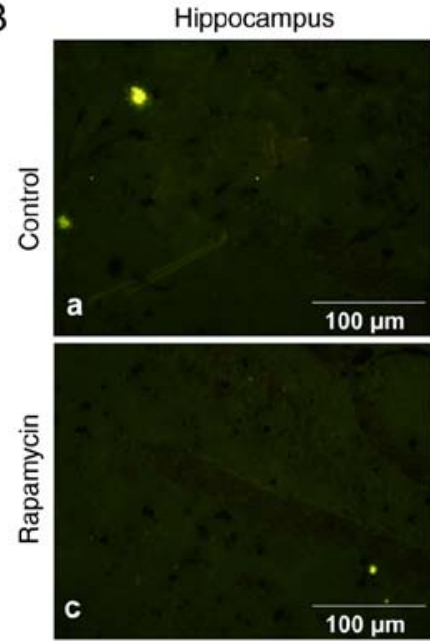

Cortex

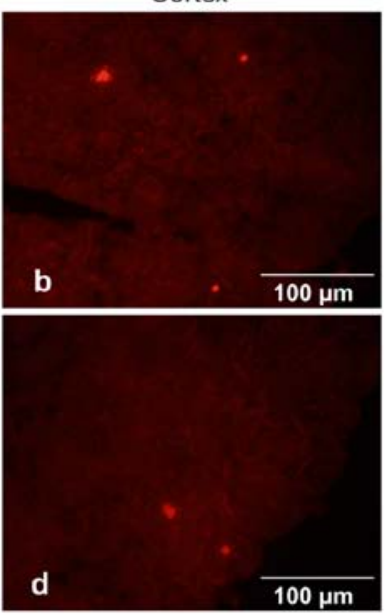

Cortex

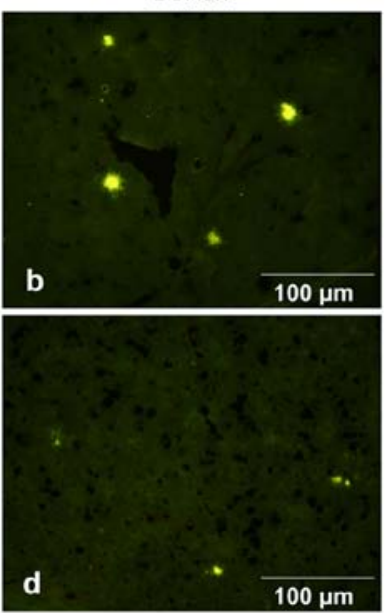

C

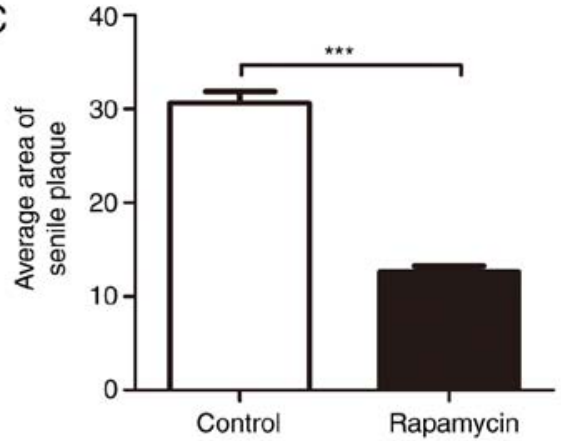

D

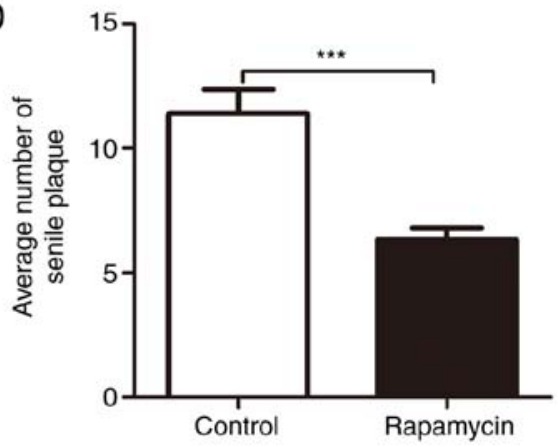

Figure 1. Rapamycin administration reduces A $\beta$ deposition. (A) Representative sections from the brains of the control group and the rapamycin-treated group immunostained with the 4G8 antibody show A $\beta$ deposition (a, c-hippocampus; b, d-cortex, scale bar: $100 \mu \mathrm{m}$ ). (B) Representative sections from the brains of the control mouse group and the rapamycin-treated mouse group stained with thioflavin $\mathrm{S}$ showing A $\beta$ aggregation (panels a and $\mathrm{c}$, hippocampus; panels $\mathrm{b}$ and d, cortex; scale bar, $100 \mu \mathrm{m})$. (C and D) Statistical graph of the average area of SPs and the number of SPs $\left({ }^{* * *} \mathrm{P}<0.001\right.$, compared with the control group). $\mathrm{A} \beta$, amyloid $\beta$-peptide; SPs, senile plaques.
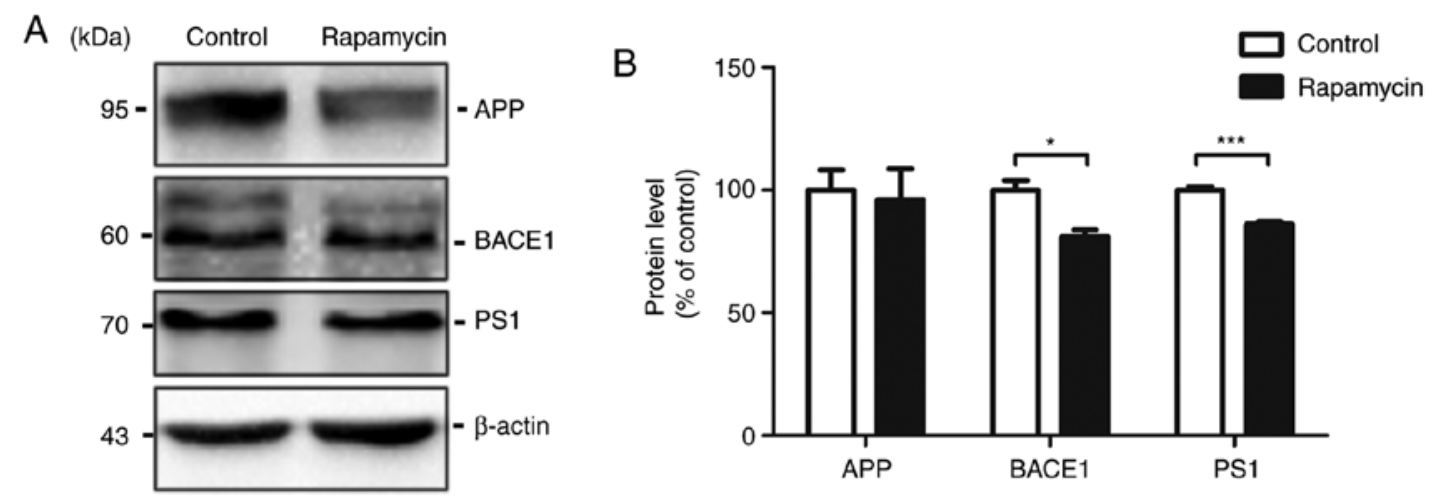

Figure 2. Rapamycin decreases the generation of A $\beta$. (A) Representative western blots of the half brain lysates of 3 mouse proteins extracted from the control group and the rapamycin-treated group and probed with the indicated antibodies. (B) Quantitative analysis of the blots is shown, and data are presented as the means \pm SEM and were analysed by a t-test $\left({ }^{*} \mathrm{P}<0.05\right.$ and ${ }^{* * *} \mathrm{P}<0.001$, compared with the control group). A $\beta$, amyloid $\beta$-peptide; APP, amyloid precursor protein; PS1, presenilin-1; BACE1, beta-secretase 1.

both autophagosomes and autolysosomes $(1.000 \pm 0.577$ vs. $20.330 \pm 5.783, \mathrm{t}=4.028, \mathrm{P}<0.05 ; \mathrm{F}=8.272, \mathrm{P}=0.019$; $0.333 \pm 0.333$ vs. $15.670 \pm 3.528, \mathrm{t}=4.066, \mathrm{P}<0.05 ; \mathrm{F}=40.77$,
$\mathrm{P}<0.001$; Fig. 6C). Additionally, the levels of autophagy-related markers were examined by western blot analysis. Compared with the control group, rapamycin treatment increased the 

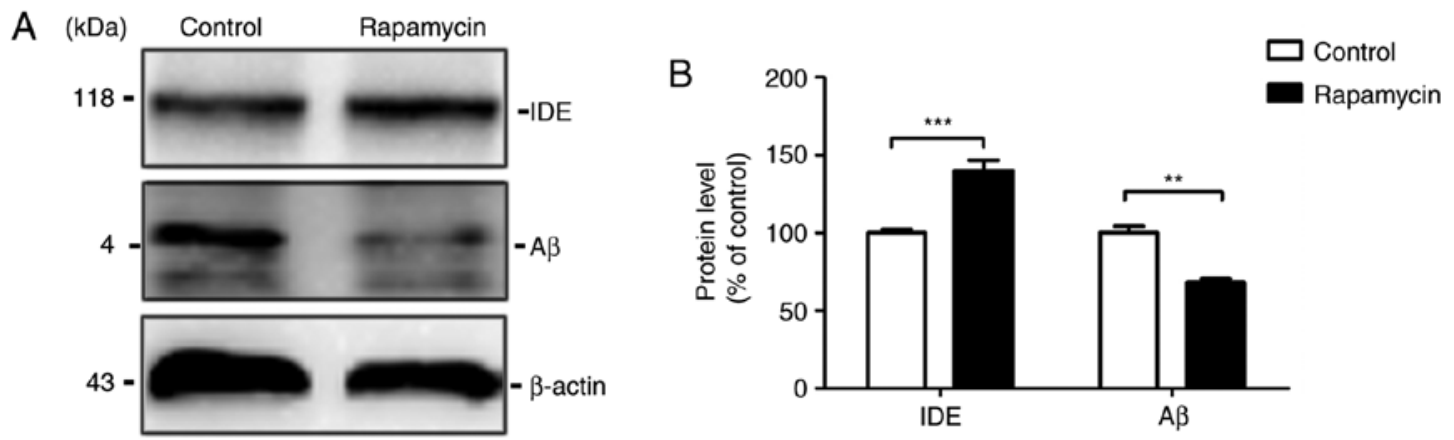

Figure 3. Rapamycin increases the proteolytic degradation of A $\beta$. (A) Representative western blots of the half brain lysates of 3 mice proteins extracted from the control group and the rapamycin-treated group and probed with the indicated antibodies. (B) Quantitative analysis of the blots is shown, and data are presented as the means \pm SEM and were analysed by a t-test $\left({ }^{* * *} \mathrm{P}<0.01\right.$ and ${ }^{* * *} \mathrm{P}<0.001$ compared with the control group). $\beta$, amyloid $\beta$-peptide; IDE, insulin degrading enzyme.
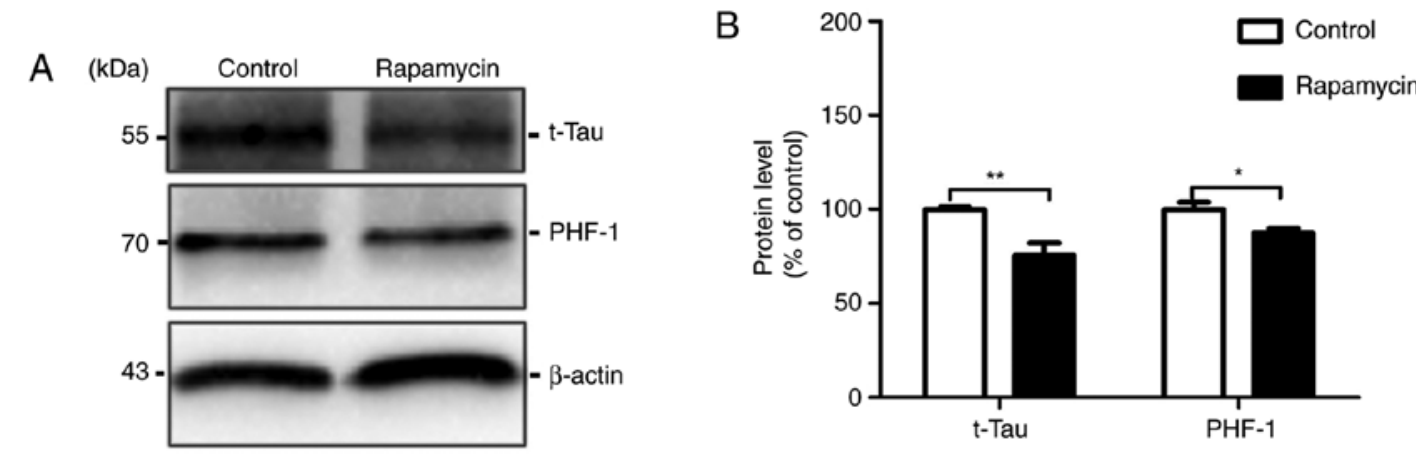

Figure 4. Rapamycin reduced Tau protein levels and hyperphosphorylation. (A) Representative western blots of the half brain lysates of 3 mice from the control mouse group and rapamycin-treated mouse group with the indicated antibodies. (B) Quantitative analysis of the blots is shown, and data are presented as the means \pm SEM and analysed by a t-test. ( $\mathrm{P}<0.05$ and ${ }^{* * *} \mathrm{P}<0.01$ compared with the control group). $\beta$, amyloid $\beta$-peptide; PHF-1, PHD finger protein 1 .

ratio of LC3-II/I (100.000 \pm 0.672 vs. $145.900 \pm 12.850, \mathrm{t}=3.565$, $\mathrm{P}=0.024)$ and the level of Beclin-1 in the brains of mice with $\mathrm{AD}(100.00 \pm 7.571$ vs. $188.4 \pm 16.590, \mathrm{t}=4.844, \mathrm{P}=0.008)$, both of which are markers of autophagy initiation. Subsequently, we measured the expression of the p62/SQSTM1 protein, which is a lysosomal degradation substrate and dysregulated autophagy increases its elimination (18). The p62 level in the rapamycin group was decreased compared with that of the control group $(100.00 \pm 2.988$ vs. $144.200 \pm 18.590, t=2.346$, $\mathrm{P}=0.041$; Fig. $6 \mathrm{D}$ and $\mathrm{E}$ ).

Rapamycin activates the $W n t / G S K 3 \beta / \beta$-Catenin signalling pathway. The Wnt and mTOR pathways have been confirmed to be linked to GSK $3 \beta$ in heart disease (19). Therefore, in this study, we detected whether rapamycin, an mTOR inhibitor, alters the Wnt pathway in AD. The results of western blot analysis revealed that Wnt3a was activated by rapamycin treatment $(100.000 \pm 3.202$ vs. $124.000 \pm 4.119, \mathrm{t}=4.593, \mathrm{P}=0.010)$ and that its downstream target protein, GSK3 $\beta$, was inhibited by rapamycin treatment $(100.00 \pm 6.805$ vs. $81.600 \pm 3.051, \mathrm{t}=2.467$, $\mathrm{P}=0.033$ ). Phosphorylation at the serine 9 residues of GSK3 $\beta$ downregulated its kinase activity, and rapamycin treatment increased phospho-GSK3 $\beta$ (Ser9) levels $(100.00 \pm 4.607$ vs. $144.700 \pm 8.587, \mathrm{t}=4.590, \mathrm{P}=0.001$ ), compared with GSK3 $\beta$. $\beta$-catenin is a target protein of GSK $3 \beta$, and the activation of GSK3 $\beta$ inhibits its activity. The $\beta$-catenin expression level in the rapamycin group was elevated compared to the control group $(100.000 \pm 0.211$ vs. $155.000 \pm 15.680, \mathrm{t}=3.509, \mathrm{P}=0.006)$. All these data suggest that rapamycin activates the Wnt pathway via the suppression of GSK3 $\beta$ (Fig. 7).

Drug safety of rapamycin as reflected by routine blood analysis and biochemical detection. Following treatment with rapamycin for 4 weeks, we first measured the drug safety of rapamycin by routine blood analysis (Table I) and chemical detection (Table II). The results of the routine blood tests and chemical detections did not differ significantly between the control and rapamycin-treated groups (all $\mathrm{P}>0.05$ ), which indicates that this dosage of rapamycin caused no toxic effects in vivo compared with the control group.

\section{Discussion}

The increased production and accumulation of $A \beta$ are the primary pathological features of AD and are closely associated with neurotoxicity and the decline in cognitive function. APP/PS1 double transgenic AD model mice are an ideal animal model with which to investigate the pathogenesis and drug targets of AD. Mutations associated with the familial form of AD are present in the amyloid precursor gene APP and in the presenilin genes 1 and 2 , which are involved in the cleavage of APP and thus in the generation of A $\beta . A \beta$ generated within cells is the suspected source of fibrillar $A \beta$ plaque deposits, and elevated intracellular $A \beta$ in the absence of SP 
A

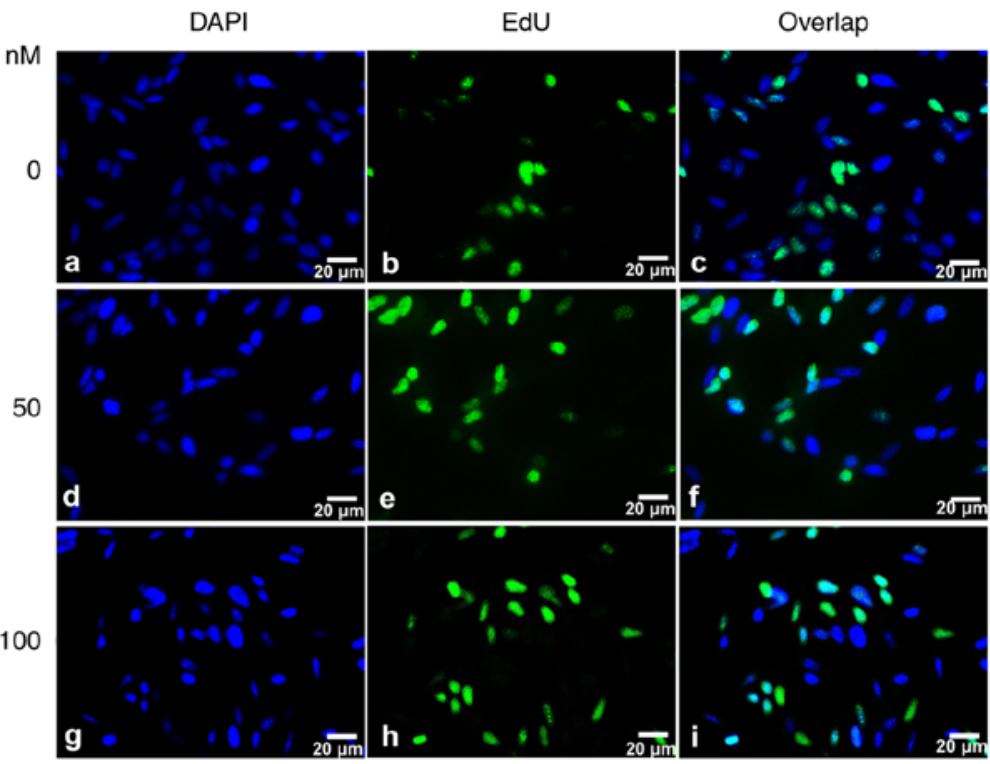

\section{B}

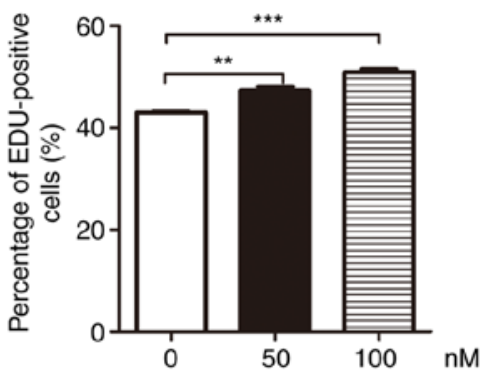

C
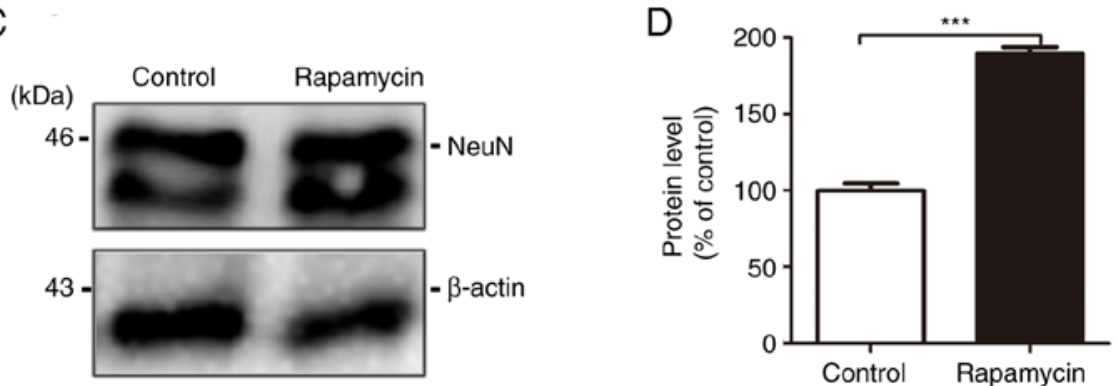

Figure 5. Rapamycin increases cell proliferation. (A) Cell proliferation and viability were determined by an EdU incorporation assay after SH-SY5Y cells stably transfected with the APPsw gene were incubated with various concentrations of rapamycin for $24 \mathrm{~h}$. Cell nuclei were counterstained with DAPI (panels a, d and g, DAPI; panels b, e and h, EdU; panels c, f and i, overlap; scale bar, $20 \mu \mathrm{m}$ ). (B) Quantitative analysis of the EdU-positive cells was performed by counting in 5 randomly selected fields of each well. Data were plotted as the means \pm SEM of 3 independent experiments were analysed by one-way ANOVA (followed by Bonferroni test) $\left({ }^{* *} \mathrm{P}<0.01\right.$ and ${ }^{* * * *} \mathrm{P}<0.001$, compared with control group, no treatment). (C) A representative western blot of NeuN levels in brain from the control group and rapamycin group. (D) Relative grey density analysis of the protein expression levels in 2 groups, and data are presented as the means \pm SEM and were analysed by Student's t-test $\left({ }^{* * * *} \mathrm{P}<0.001\right.$, compared with control group).

formation has been reported to be accompanied by cognitive deficits (20). A $\beta$ is produced from APP processing, in which APP can be sequentially cleaved by $\beta$-secretase (BACE1) and $\gamma$-secretase (PS1) to produce amyloidogenic peptides. In addition, the dynamic balance of $A \beta$ is maintained by its production and degradation. Several proteases can regulate the degradation of $A \beta$, such as neprilysin (NEP), zinc metallopeptidases, and the carefully studied IDE $(21,22)$. IDE is a zinc-endopeptidase that is well known for its activity against insulin and glucagon (23). However, recent studies have confirmed that IDE is a major endogenous $A \beta$-degrading enzyme. Additionally, IDE has been found to increase the secretion induced by $A \beta$ in the presence of autophagy from astrocytes (24). Rapamycin-activated autophagy in conjunction with increased IDE secretion from astrocytes and IDE located in autophagosomes was discovered in a previous study. These findings imply that the IDE secretion induced by $A \beta$ is regulated by autophagy, which is in accordance with the conclusion of this study. In this study, the results of immunofluorescence revealed that rapamycin treatment reduced SP formation and deposition. The results of western blot analysis demonstrated that rapamycin decreased the expression levels of BACE1, PS1 and A $\beta$, and increase the level of IDE, which illustrates that rapamycin can ameliorate $A \beta$ accumulation, by not only enhancing autophagy activity, but also by reducing APP cleavage and increasing the proteolytic degradation of $A \beta$.

Tau is the most abundant microtubule-associated protein in the brain. Under physiological conditions, the function of Tau is to combine with microtubules to promote microtubule stabilization. However, by contrast, under pathological conditions, Tau exhibits altered solubility properties, is abnormally hyperphosphorylated at certain residues and forms PHF structures, which are prone to form NFTs $(17,25,26)$. It has been confirmed that Tau can be eliminated by autophagy under pathological conditions $(27,28)$. The inactivation of autophagy leads to the accumulation of hyperphosphorylated Tau, and the activation of autophagy results in a reduction in hyperphosphorylated Tau levels (29). Notably, it has been demonstrated that different lengths of Tau may be degraded through different autophagic pathways; the full-length Tau is preferentially degraded through macroautophagy, whereas truncated Tau (for one, TauRD $\Delta \mathrm{K} 280$ ) is cleared through chaperone-mediated autophagy (30). Although the APP/PS1/Tau tri-transgenic AD mouse model is an ideal model with which to study the pathology of $A \beta$ and Tau, the tau-induced pathology in the 
A

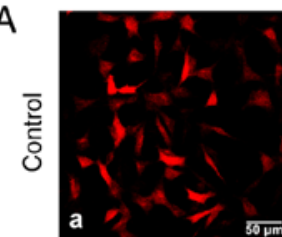
MRFP-LC3
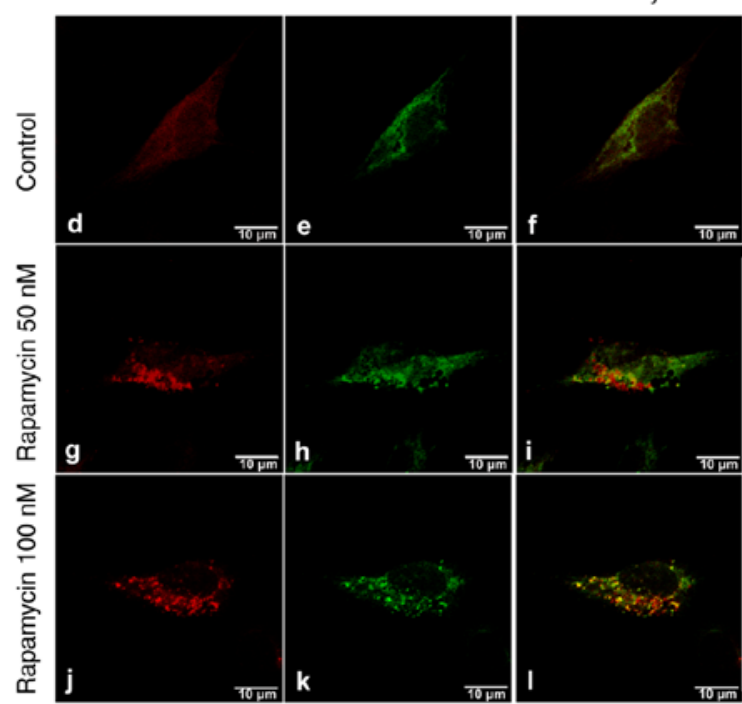

B

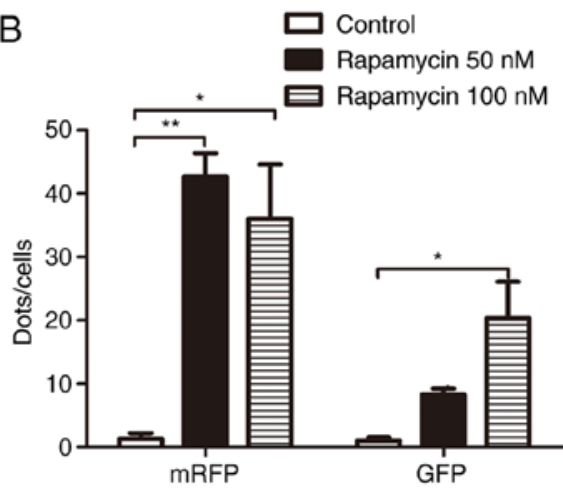

C

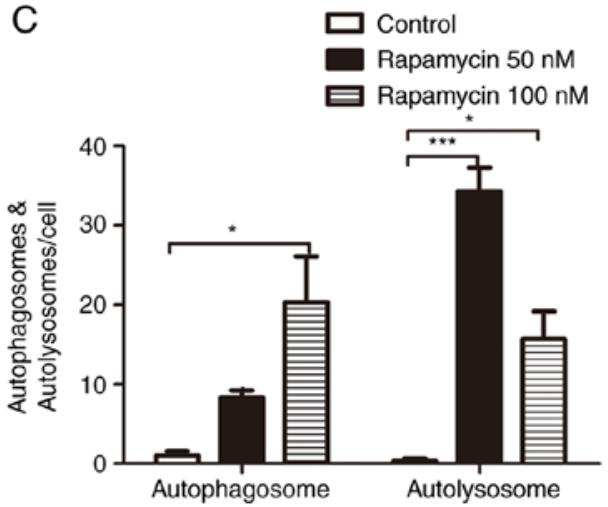

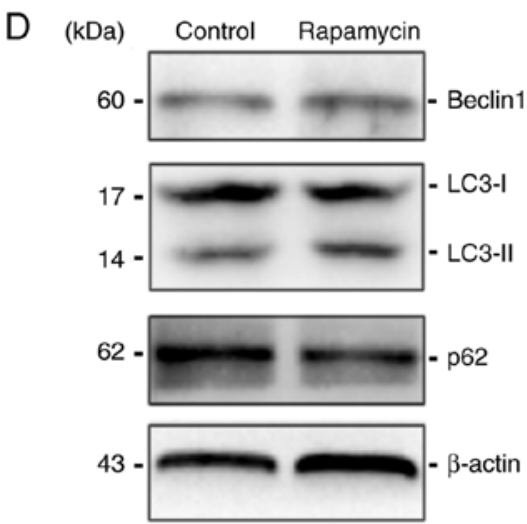

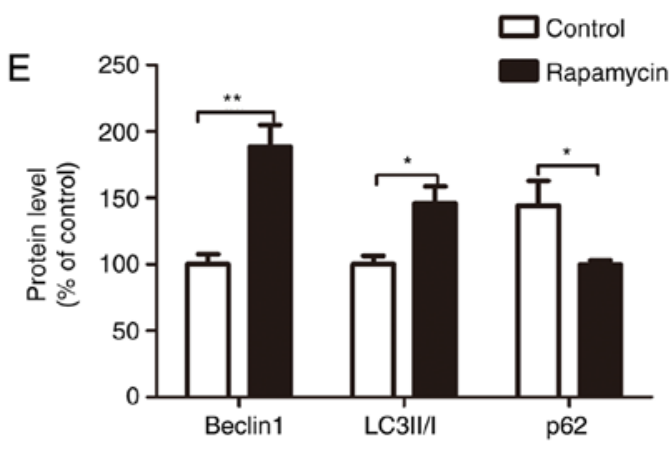

Figure 6. Rapamycin activates autophagy. (A) Fluorescent microscopy images of differentiated SH-SY5Y cells stably transfected with the APPsw gene expressing mRFP-GFP-LC3 and treated with 50 or $100 \mathrm{nM}$ rapamycin or vehicle for $24 \mathrm{~h}$. The efficiency of transfection were also shown (panels a, d, g and j, mRFP; panels b, e, h and k, GFP; panels c, f, i and 1, overlap; scale bar, $10 \mu \mathrm{m}$ ). (B) Quantification of mRFP and GFP puncta per cell. Five randomly selected fields were counted and the data are presented as the means \pm SEM and were analysed by one-way ANOVA (followed by Bonferroni test) $\left({ }^{* *} \mathrm{P}<0.05,{ }^{* *} \mathrm{P}<0.01\right.$ and ${ }^{* * * *} \mathrm{P}<0.001$, compared with the control group). (C) Quantification of autophagosomes and autolysosomes per cell. Five randomly selected fields were counted. The data were presented as the means \pm SEM and were analysed by one-way ANOVA (followed by Bonferroni test). (D) Representative western blots of Beclin1, LC3 and p62 levels in the brain in the control group and the rapamycin group. (E) Relative grey density analysis of protein expression levels in the 2 groups is shown, and the data are presented as the means \pm SEM and were analysed by a Student's $t$-test ( $\mathrm{P}<0.05$ and ${ }^{* *} \mathrm{P}<0.01$, compared with the control group).

APP/PS1 double-transgenic AD mouse model was also found in our previous study and in other reports (31-33). This study examined the effects of rapamycin on Tau clearance. The results of western blot analysis indicated that rapamycin treatment decreased the expression levels of Tau-5 and PHF-1, suggesting that rapamycin contributed to the degradation of not only full-length Tau, but also phosphorylated Tau.

AD is characterized by neuronal cell death, which eventually leads to memory loss. Neurons are post-mitotic cells that are unable to degrade the toxic substances accumulated during the ageing processes with mitosis; thus autophagy is an important mechanism for clearing abnormally aggregated proteins in neuronal cells (34). It is becoming evident that autophagy is a protective reaction in neurons and that dysfunctional autophagy aggravates neuronal death in $\mathrm{AD}$ (35-37). NeuN, a marker of neuronal differentiation, is a nuclear protein expressed in most post-mitotic neurons in the nervous system and plays an important role in nervous system development and function (38). This study found that rapamycin treatment elevated NeuN expression levels and the number of EdU-positive cells, which indicates that rapamycin can increase cell proliferation and may exert a neuroprotective effect in AD.

Autophagy is a catabolic mechanism responsible for the clearance of intracellular cytosolic components, including 

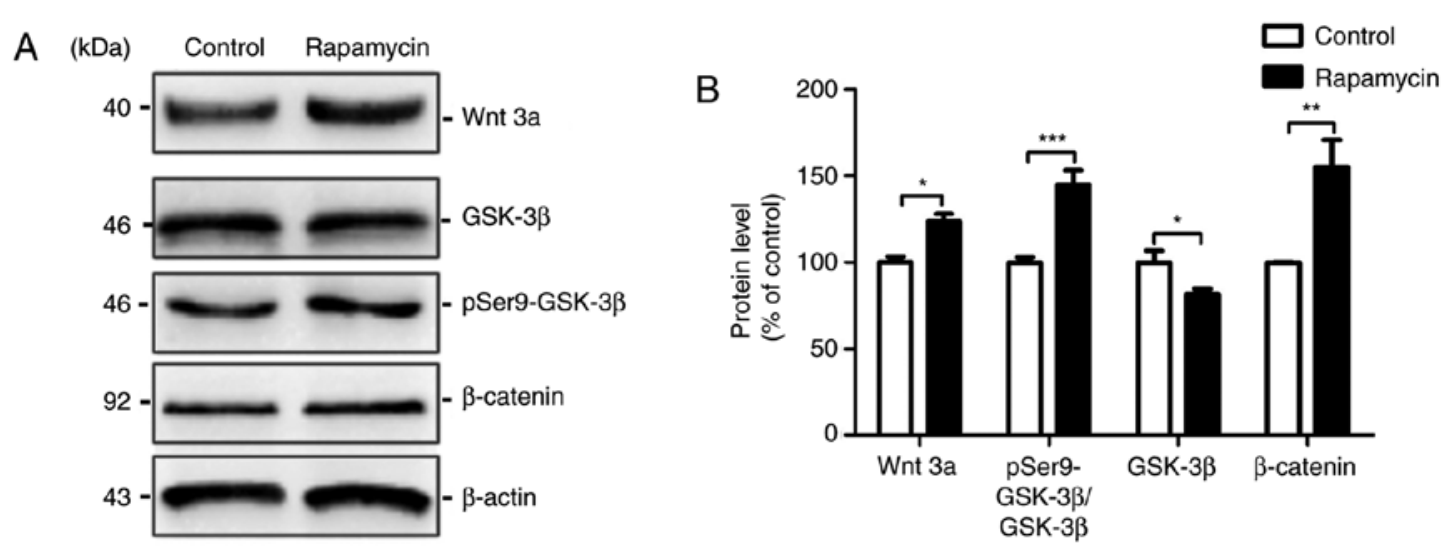

Figure 7. Alteration of the Wnt/GSK3 $/ \beta$-Catenin signalling pathway via rapamycin administration were detected by western blot analysis. (A) The protein expression levels of Wnt3a, GSK3 $\beta$, p-GSK3 $\beta$ and $\beta$-catenin were detected by western blot analysis (one representative image is shown, $n=3$ ). (B) Quantitative analyses of Wnt3a, GSK3 $\beta$, p-GSK3 $\beta$ and $\beta$-catenin by immunoreactivity in the lysates of half brains from the control and rapamycin-treated groups. Data are presented as the means \pm SEM and were analysed by a t-test $\left({ }^{*} \mathrm{P}<0.05,{ }^{* *} \mathrm{P}<0.01\right.$ and ${ }^{* * * *} \mathrm{P}<0.001$, compared with the control group). GSK3 $\beta$, glycogen synthase kinase $3 \beta$.

Table I. Routine blood analysis following rapamycin treatment in mice (compared with the control group ( $\mathrm{P}>0.05$ ).

\begin{tabular}{lcc}
\hline Indexes & Control group & Rapamycin group \\
\hline RBC $\left(\times 10^{12} / \mathrm{l}\right)$ & $10.7 \pm 0.6$ & $10.5 \pm 0.3$ \\
HGB $(\mathrm{g} / \mathrm{l})$ & $147.7 \pm 16.2$ & $145.7 \pm 2.3$ \\
MCV $(\mathrm{fl})$ & $43.4 \pm 1.4$ & $44.9 \pm 0.2$ \\
WBC $\left(\times 10^{9} / \mathrm{l}\right)$ & $10.4 \pm 2.3$ & $8.5 \pm 6.6$ \\
PLT $\left(\times 10^{9} / \mathrm{l}\right)$ & $989.3 \pm 278.6$ & $1,140.0 \pm 50.8$ \\
MPV (fl) & $6.5 \pm 0.1$ & $6.7 \pm 0.1$ \\
\hline
\end{tabular}

Table II. Biochemical detection of rapamycin administration effects on mice (compared with control group, $\mathrm{P}>0.05$ ).

\begin{tabular}{lcc}
\hline Indexes & Control group & Rapamycin group \\
\hline ALT (U/l) & $41.3 \pm 4.0$ & $43.3 \pm 4.2$ \\
AST (U/l) & $143.7 \pm 44.8$ & $137.3 \pm 38.9$ \\
BUN (mmol/l) & $11.2 \pm 0.6$ & $10.8 \pm 2.0$ \\
Scr $(\mu \mathrm{mol} / \mathrm{l})$ & $11.1 \pm 0.6$ & $11.8 \pm 1.0$ \\
TBIL $(\mu \mathrm{mol} / \mathrm{l})$ & $0.8 \pm 0.8$ & $0.6 \pm 0.7$ \\
TG $(\mathrm{mmol} / \mathrm{l})$ & $1.0 \pm 0.1$ & $1.1 \pm 0.5$ \\
\hline
\end{tabular}

misfolded proteins, aggregates and organelles, and it has now been confirmed to play a crucial role in AD pathology. Properly functioning autophagy is essential for neuronal metabolism, and the lack of autophagy in the central nervous system (CNS) leads to neurodegeneration; for example, inactivating autophagy impairs neuronal homeostasis $(29,39)$. Autophagy is initiated when an 'isolation membrane' appears. Subsequently, the membrane elongates, engulfing cellular components to form autophagosomes (APs) and lysosomes, which can digest the cargo in their acidic environment, fuse with APs to generate autolysosomes (ALs). Recent studies have found that the expression of autophagy-related genes is downregulated with ageing; a deficiency in Beclin1, a key protein in autophagy induction, results in increases in $A \beta$ levels, whereas its overexpression reduces the accumulation of $A \beta(40-43)$. These studies have indicated that autophagic activity is reduced with ageing, and the reduction of autophagy contributes to the onset of AD. Several studies which have focused on autophagy have discovered that the activation of autophagy can decrease abnormal $A \beta$ aggregation in neurons and can alleviate neurotoxicity (44-48), which is consistent with the results of this study.

The transfection of cells with the mRFP-GFP-LC3 adenoviral vector allows for the visualization of autophagic activity. Upon rapamycin exposure, the cells accumulate dense red and yellow puncta, which represents autolysosomes and autophagosomes, respectively. The present study on rapamycin found that treatment with rapamycin increased the number of autolysosomes and autophagosomes. However, the results of western blot analysis indicated that rapamycin treatment increased the ratio of LC3-II/I and elevated the expression of Beclin1, both of which are crucial mediators of autophagy induction. p62 protein is a lysosomal degradation substrate that reduces when autophagy begins and the autophagic flux proceeds smoothly (18). In this study, the p62 expression level decreased following rapamycin treatment, which demonstrated the increased degradation mediated by autophagy.

GSK $3 \beta$ is one of the phosphorylating glycogen synthase enzymes (49). In the brain, GSK3 $\beta$ is involved in a number of cellular processes and mediates several signalling pathways (50-52). Researchers have reported that $A \beta$ leads to GSK $3 \beta$ activation, and the inhibition of GSK3 $\beta$ has been verified to reduce $A \beta$ production and decrease $A \beta$-induced neurotoxicity $(53,54)$. It is well known that GSK $3 \beta$ has the exact site for the hyperphosphorylation of Tau protein. The excessive activation of GSK $3 \beta$ increases hyperphosphorylated Tau protein production, and GSK $3 \beta$ itself is involved in the initiation and development of AD (55). GSK $3 \beta$ is most commonly mediated by inhibitory phosphorylation at the Ser9 site residue, and this serine can be phosphorylated by several kinases; thus, multiple signalling pathways 
are involved in its regulation, such as the PI3k/Akt/mTOR pathway and the Wnt pathway. It has been reported that GSK3 $\beta$ functions in several pathways which regulate the cellular homeostasis of energy and growth, including those mediated by PI3K and AKT, mTOR and MAPK. The inhibition of mTOR by rapamycin leads to the inactivation of its target kinases, including AKT, p70S6K and p85S6K, which in turn promotes GSK3 $\beta$ activation (56-59). The Wnt pathway is also involved in the onset of AD. Wnt signalling is an autocrine signal transduction pathway that participates in brain development $(60,61)$. The ablation of Wnt-3a, a Wnt ligand, results in the disappearance of the hippocampus $(62,63)$. Wnt signalling can be mainly divided into two types: $\beta$-catenin-dependent signalling (Wnt/ $\beta$-catenin) and $\beta$-catenin-independent signalling $(64,65)$. GSK $3 \beta$ is a crucial regulator of the $\mathrm{Wnt} / \beta$-catenin pathway. The activation of GSK $3 \beta$ by Wnt signalling results in the phosphorylation and degradation of its downstream target, $\beta$-catenin (66). Without Wnt stimulation, the phosphorylation of $\beta$-catenin prevents transcriptional activity in the nucleus.

In this study, 4 weeks of rapamycin administration significantly activated the Wnt pathway, which led to an increased Wnt $3 \mathrm{a}$ and a reduced GSK $3 \beta$ expression. The phosphorylation of GSK3 $\beta$ at Ser9 reduced the activation of GSK $3 \beta$, and treatment with rapamycin seemed to reduce the activity of GSK3$\beta$. It has been reported that the overexpression of GSK $3 \beta$ in neurons decreases nuclear $\beta$-catenin levels and increases Tau hyperphosphorylation in the hippocampus (10). In this study, the results of western blot analysis indicated that rapamycin treatment increased the expression level of $\beta$-catenin.

It has been reported that rapamycin improves learning after sepsis by enhancing autophagy and may be a potentially effective therapeutic agent for the treatment of sepsis-induced cognitive impairment $(67,68)$. In this study, the data imply that rapamycin can increase cell proliferation as well as reduce $\mathrm{A} \beta$ and Tau pathology by inducing autophagy and activating the Wnt/GSK $3 \beta / \beta$-catenin signalling pathway. Thus, rapamycin may be a potential therapy with which to prevent the progression of AD.

Rapamycin is a macrolide antibiotic produced by Streptomyces hygroscopicus, and a previous study found that rapamycin is an inhibitor of mTOR, which is a major signalling molecule that suppresses the initiation step of autophagy (69). Notably, GSK $3 \beta$ is a key regulator of many cellular signalling pathways, and the mTOR pathway is one of these pathways. However, the effect of rapamycin on the GSK $3 \beta$ signalling pathway has not yet been clearly elucidated. The purpose of the present study was to analyse the effects of rapamycin on AD progression, autophagy activity, and GSK3 $\beta$ function, as well as the underlying mechanisms of action of rapamycin in APP/PS1 double transgenic mice.

\section{Acknowledgements}

The authors would like to thank Professor Kejian Wang (Department of Anatomy, Chongqing Medical University), Professor Weihong Song (University of British Columbia) and Professor Zhifang Dong (Children's Hospital Affiliated to Chongqing Medical University) for their assistance with performing the experiments.

\section{Funding}

This study was supported by the National Natural Science Foundation of China (nos. 31670899, 81671257, 81371221 and 31600825); the Basic and Frontier Research Project of Chongqing (cstc2016jcyjA0244; cstc2016jcyjA0069); and the Education Commission Science and Technology Research Project of Chongqing (no. KJ1500231).

\section{Availability of data and materials}

All data generated or analyzed during this study are included in this published article.

\section{Authors' contributions}

GH and SL conceived and designed the study. JC and ZL performed the experiments and drafted the manuscript, YL and ML conducted the statistical analysis. All authors have read and approved the final manuscript.

\section{Ethics approval and consent to participate}

All procedures involving animals were performed under institutional guidelines. This study was approved by The Ethics Committee of Chongqing Medical University (SCXK 2014-0004).

\section{Patient consent for publication}

Not applicable.

\section{Competing interests}

The authors declare that they have no competing interests.

\section{References}

1. Hardy J and Selkoe DJ: The amyloid hypothesis of Alzheimer's disease: Progress and problems on the road to therapeutics. Science 297: 353-356, 2002.

2. Mucke L: Neuroscience: Alzheimer's disease. Nature 461: 895-897, 2009.

3. Näslund J, Haroutunian V, Mohs R, Davis KL, Davies P, Greengard P and Buxbaum JD: Correlation between elevated levels of amyloid beta-peptide in the brain and cognitive decline. JAMA 283: 1571-1577, 2000.

4. Karran E, Mercken M and De Strooper B: The amyloid cascade hypothesis for Alzheimer's disease: An appraisal for the development of therapeutics. Nat Rev Drug Discov 10: 698-712, 2011.

5. Sun X, Sato S, Murayama O, Murayama M, Park JM, Yamaguchi $\mathrm{H}$ and Takashima A: Lithium inhibits amyloid secretion in COS7 cells transfected with amyloid precursor protein C100. Neurosci Lett 321: 61-64, 2002.

6. Li B, Ryder J, Su Y, Zhou Y, Liu F and Ni B: FRAT1 peptide decreases Abeta production in swAPP(751) cells. FEBS Lett 553: 347-350, 2003.

7. Su Y, Ryder J, Li B, Wu X, Fox N, Solenberg P, Brune K, Paul S Zhou Y, Liu F and Ni B: Lithium, a common drug for bipolar disorder treatment, regulates amyloid-beta precursor protein processing. Biochemistry 43: 6899-6908, 2004

8. LyPT,Wu Y,ZouH,WangR,ZhouW,Kinoshita A,Zhang M, Yang Y Cai F, Woodgett $\mathbf{J}$ and Song W: Inhibition of GSK3 $\beta$-mediated BACE1 expression reduces Alzheimer-associated phenotypes. J Clin Invest 123: 224-235, 2013.

9. Brownlees J, Irving NG, Brion JP, Gibb BJ, Wagner U, Woodgett $\mathrm{J}$ and Miller CC: Tau phosphorylation in transgenic mice expressing glycogen synthase kinase-3beta transgenes. Neuroreport 8: 3251-3255, 1997. 
10. Lucas JJ, Hernández F, Gómez-Ramos P, Morán MA, Hen R and Avila J: Decreased nuclear beta-catenin, tau hyperphosphorylation and neurodegeneration in GSK-3beta conditional transgenic mice. EMBO J 20: 27-39, 2001.

11. Engel T, Hernández F, Avila J and Lucas JJ: Full reversal of Alzheimer's disease-like phenotype in a mouse model with conditional overexpression of glycogen synthase kinase-3. J Neurosci 26: 5083-5090, 2006

12. Ghanevati M and Miller CA: Phospho-beta-catenin accumulation in Alzheimer's disease and in aggresomes attributable to proteasome dysfunction. J Mol Neurosci 25: 79-94, 2005.

13. De Ferrari GV, Papassotiropoulos A, Biechele T, Wavrant DeVrieze F, Avila ME, Major MB, Myers A, Sáez K, Henríquez JP, Zhao A, et al: Common genetic variation within the low-density lipoprotein receptor-related protein 6 and late-onset Alzheimer's disease. Proc Natl Acad Sci USA 104: 9434-9439, 2007.

14. Paccalin M, Pain-Barc S, Pluchon C, Paul C, Besson MN, Carret-Rebillat AS, Rioux-Bilan A, Gil R and Hugon J: Activated mTOR and PKR kinases in lymphocytes correlate with memory and cognitive decline in Alzheimer's disease. Dement Geriatr Cogn Disord 22: 320-326, 2006.

15. Yang Z and Klionsky DJ: Mammalian autophagy: Core molecular machinery and signaling regulation. Curr Opin Cell Biol 22: $124-131,2010$.

16. Spilman P, Podlutskaya N, Hart MJ, Debnath J, Gorostiza O, Bredesen D, Richardson A, Strong R and Galvan V: Inhibition of mTOR by rapamycin abolishes cognitive deficits and reduces amyloid-beta levels in a mouse model of Alzheimer's disease. PLoS One 5: e9979, 2010.

17. Alonso A, Zaidi T, Novak M, Grundke-Iqbal I and Iqbal K Hyperphosphorylation induces self-assembly of tau into tangles of paired helical filaments/straight filaments. Proc Natl Acad Sci USA 98: 6923-6928, 2001.

18. Mathew R, Karp CM, Beaudoin B, Vuong N, Chen G, Chen HY, Bray K, Reddy A, Bhanot G, Gelinas C, et al: Autophagy suppresses tumorigenesis through elimination of p62. Cell 137: 1062-1075, 2009

19. Vigneron F, Dos Santos P, Lemoine S, Bonnet M, Tariosse L, Couffinhal T, Duplaà C and Jaspard-Vinassa B: GSK-3 $\beta$ at the crossroads in the signalling of heart preconditioning: Implication of mTOR and Wnt pathways. Cardiovasc Res 90: 49-56, 2011.

20. LaFerla FM, Green KN and Oddo S: Intracellular amyloid-beta in Alzheimer's disease. Nat Rev Neurosci 8: 499-509, 2007.

21. Iwata N, Tsubuki S, Takaki Y, Shirotani K, Lu B, Gerard NP, Gerard C, Hama E, Lee HJ and Saido TC: Metabolic regulation of brain Abeta by neprilysin. Science 292: 1550-1552, 2001.

22. Farris W, Mansourian S, Chang Y, Lindsley L, Eckman EA, Frosch MP, Eckman CB, Tanzi RE, Selkoe DJ and Guenette S: Insulin-degrading enzyme regulates the levels of insulin, amyloid beta-protein, and the beta-amyloid precursor protein intracellular domain in vivo. Proc Natl Acad Sci USA 100 4162-4167, 2003.

23. Qiu WQ, Walsh DM, Ye Z, Vekrellis K, Zhang J, Podlisny MB, Rosner MR, Safavi A,Hersh LB and Selkoe DJ: Insulin-degrading enzyme regulates extracellular levels of amyloid beta-protein by degradation. J Biol Chem 273: 32730-32738, 1998.

24. Son SM, Cha MY, Choi H, Kang S, Choi H, Lee MS, Park SA and Mook-Jung I: Insulin-degrading enzyme secretion from astrocytes is mediated by an autophagy-based unconventional secretory pathway in Alzheimer disease. Autophagy 12: 784-800, 2016.

25. Ballatore C, Lee VM and Trojanowski JQ: Tau-mediated neurodegeneration in Alzheimer's disease and related disorders. Nat Rev Neurosci 8: 663-672, 2007.

26. Grundke-Iqbal I, Iqbal K, Tung YC, Quinlan M, Wisniewski HM and Binder LI: Abnormal phosphorylation of the microtubule-associated protein tau (tau) in Alzheimer cytoskeletal pathology. Proc Natl Acad Sci USA 83: 4913-4917, 1986.

27. Rubinsztein DC: The roles of intracellular protein-degradation pathways in neurodegeneration. Nature 443: 780-786, 2006.

28. Chesser AS, Pritchard SM and Johnson GV: Tau clearance mechanisms and their possible role in the pathogenesis of Alzheimer disease. Front Neurol 4: 122, 2013

29. Hara T, Nakamura K, Matsui M, Yamamoto A, Nakahara Y, Suzuki-Migishima R, Yokoyama M, Mishima K, Saito I, Okano H and Mizushima N: Suppression of basal autophagy in neural cells causes neurodegenerative disease in mice. Nature 441: 885-889, 2006
30. Wang Y, Martinez-Vicente M, Krüger U, Kaushik S, Wong E, Mandelkow EM, Cuervo AM and Mandelkow E: Tau fragmentation, aggregation and clearance: The dual role of lysosomal processing. Hum Mol Genet 18: 4153-4170, 2009.

31. Long ZM, Zhao L, Jiang R, Wang KJ, Luo SF, Zheng M, Li XF and He GQ: Valproic acid modifies synaptic structure and accelerates neurite outgrowth via the glycogen synthase kinase- $3 \beta$ signaling pathway in an Alzheimer's disease model. CNS Neurosci Ther 21: 887-897, 2015.

32. Kempf SJ, Metaxas A, Ibáñez-Vea M, Darvesh S, Finsen B and Larsen MR: An integrated proteomics approach shows synaptic plasticity changes in an APP/PS1 Alzheimer's mouse model. Oncotarget 7: 33627-33648, 2016.

33. Zhong L, Liu H, Zhang W, Liu X, Jiang B, Fei H and Sun Z: Ellagic acid ameliorates learning and memory impairment in APP/PS1 transgenic mice via inhibition of $\beta$-amyloid production and tau hyperphosphorylation. Exp Ther Med 16: 4951-4958, 2018.

34. Mariño G, Madeo F and Kroemer G: Autophagy for tissue homeostasis and neuroprotection. Curr Opin Cell Biol 23: 198-206, 2011.

35. Pivtoraiko VN, Harrington AJ, Mader BJ, Luker AM, Caldwell GA, Caldwell KA, Roth KA and Shacka JJ: Low-dose bafilomycin attenuates neuronal cell death associated with autophagy-lysosome pathway dysfunction. J Neurochem 114: 1193-1204, 2010

36. Chu CT: Autophagy in different flavors: Dysregulated protein degradation in neurological diseases. Neurobiol Dis 43: 1-3, 2011.

37. Galluzzi L, Maiuri MC, Vitale I, Zischka H, Castedo M, Zitvogel L and Kroemer G: Cell death modalities: Classification and pathophysiological implications. Cell Death Differ 14: 1237-1243, 2007.

38. Mullen RJ, Buck CR and Smith AM: NeuN, a neuronal specific nuclear protein in vertebrates. Development 116: 201-211, 1992.

39. Komatsu M, Waguri S, Chiba T, Murata S, Iwata J, Tanida I, Ueno T, Koike M, Uchiyama Y, Kominami E and Tanaka K: Loss of autophagy in the central nervous system causes neurodegeneration in mice. Nature 441: 880-884, 2006.

40. Omata Y, Lim YM, Akao Y and Tsuda L: Age-induced reduction of autophagy-related gene expression is associated with onset of Alzheimer's disease. Am J Neurodegener Dis 3: 134-142, 2014.

41. Salminen A, Kaarniranta K, Kauppinen A, Ojala J, Haapasalo A, Soininen $\mathrm{H}$ and Hiltunen M: Impaired autophagy and APP processing in Alzheimer's disease: The potential role of Beclin 1 interactome. Prog Neurobiol 106-107: 33-54, 2013.

42. Jaeger PA, Pickford F, Sun CH, Lucin KM, Masliah E and Wyss-Coray T: Regulation of amyloid precursor protein processing by the Beclin 1 complex. PLoS One 5: e11102, 2010.

43. Pickford F, Masliah E, Britschgi M, Lucin K, Narasimhan R, Jaeger PA, Small S, Spencer B, Rockenstein E, Levine B and Wyss-Coray T: The autophagy-related protein beclin 1 shows reduced expression in early Alzheimer disease and regulates amyloid beta accumulation in mice. J Clin Invest 118: 2190-2199, 2008.

44. Sarkar S, Perlstein EO, Imarisio S, Pineau S, Cordenier A, Maglathlin RL, Webster JA, Lewis TA, O'Kane CJ, Schreiber SL and Rubinsztein DC: Small molecules enhance autophagy and reduce toxicity in Huntington's disease models. Nat Chem Biol 3: 331-338, 2007.

45. Williams A, Sarkar S, Cuddon P, Ttofi EK, Saiki S, Siddiqi FH, Jahreiss L, Fleming A, Pask D, Goldsmith P, et al: Novel targets for Huntington's disease in an mTOR-independent autophagy pathway. Nat Chem Biol 4: 295-305, 2008.

46. Balgi AD, Fonseca BD, Donohue E, Tsang TC, Lajoie P, Proud CG, Nabi IR and Roberge M: Screen for chemical modulators of autophagy reveals novel therapeutic inhibitors of mTORC1 signaling. PLoS One 4: e7124, 2009.

47. Jimenez-Sanchez M, Thomson F, Zavodszky E and Rubinsztein DC: Autophagy and polyglutamine diseases. Prog Neurobiol 97: 67-82, 2012.

48. Bové J, Martinez-Vicente M and Vila M: Fighting neurodegeneration with rapamycin: Mechanistic insights. Nat Rev Neurosci 12: 437-452, 2011

49. Embi N,Rylatt DB and Cohen P: Glycogen synthase kinase-3 from rabbit skeletal muscle. Separation from cyclic-AMP-dependent protein kinase and phosphorylase kinase. Eur J Biochem 107: 519-527, 1980.

50. Doble BW and Woodgett JR: Role of glycogen synthase kinase-3 in cell fate and epithelial-mesenchymal transitions. Cells Tissues Organs 185: 73-84, 2007.

51. Forde JE and Dale TC: Glycogen synthase kinase 3: A key regulator of cellular fate. Cell Mol Life Sci 64: 1930-1944, 2007. 
52. Llorens-Martin M, Jurado J, Hernández F and Avila J: GSK-3 $\beta$, a pivotal kinase in Alzheimer disease. Front Mol Neurosci 7: 46, 2014.

53. Rockenstein E, Torrance M, Adame A, Mante M, Bar-on P, Rose JB, Crews L and Masliah E: Neuroprotective effects of regulators of the glycogen synthase kinase-3beta signaling pathway in a transgenic model of Alzheimer's disease are associated with reduced amyloid precursor protein phosphorylation. J Neurosci 27: 1981-1991, 2007.

54. Koh SH, Noh MY and Kim SH: Amyloid-beta-induced neurotoxicity is reduced by inhibition of glycogen synthase kinase-3. Brain Res 1188: 254-262, 2008.

55. Terwel D, Muyllaert D, Dewachter I, Borghgraef P, Croes S, Devijver H and Van Leuven F: Amyloid activates GSK-3beta to aggravate neuronal tauopathy in bigenic mice. Am J Pathol 172: 786-798, 2008

56. Lin SY, Li TY, Liu Q, Zhang C, Li X, Chen Y, Zhang SM, Lian G, Liu Q, Ruan K, et al: GSK3-TIP60-ULK1 signaling pathway links growth factor deprivation to autophagy. Science 336: 477-481, 2012.

57. Cohen P and Frame S: The renaissance of GSK3. Nat Rev Mol Cell Biol 2: 769-776, 2001.

58. Woodgett JR and Ohashi PS: GSK3: An in-Toll-erant protein kinase? Nat Immunol 6: 751-752, 2005.

59. Zhang HH, Lipovsky AI, Dibble CC, Sahin M and Manning BD: S6K1 regulates GSK3 under conditions of mTOR-dependent feedback inhibition of Akt. Mol Cell 24: 185-197, 2006.

60. Salinas PC and Zou Y: Wnt signaling in neural circuit assembly. Annu Rev Neurosci 31: 339-358, 2008.
61. Inestrosa $\mathrm{NC}$ and Arenas E: Emerging roles of Wnts in the adult nervous system. Nat Rev Neurosci 11: 77-86, 2010.

62. Moon RT, Kohn AD, De Ferrari GV and Kaykas A: WNT and beta-catenin signalling: Diseases and therapies. Nat Rev Genet 5: 691-701, 2004.

63. Ciani L and Salinas PC: WNTs in the vertebrate nervous system: From patterning to neuronal connectivity. Nat Rev Neurosci 6: 351-362, 2005.

64. Logan CY and Nusse R: The Wnt signaling pathway in development and disease. Annu Rev Cell Dev Biol 20: 781-810, 2004.

65. Gordon MD and Nusse R: Wnt signaling: Multiple pathways, multiple receptors, and multiple transcription factors. J Biol Chem 281: 22429-22433, 2006.

66. Inestrosa NC, Montecinos-Oliva C and Fuenzalida M: Wnt signaling: Role in Alzheimer disease and schizophrenia. J Neuroimmune Pharmacol 7: 788-807, 2012.

67. Lin AL, Jahrling JB, Zhang W, DeRosa N, Bakshi V, Romero P, Galvan V and Richardson A: Rapamycin rescues vascular, metabolic and learning deficits in apolipoprotein E4 transgenic mice with pre-symptomatic Alzheimer's disease. J Cereb Blood Flow Metab 37: 217-226, 2017.

68. Liu W, Guo J, Mu J, Tian L and Zhou D: Rapamycin protects sepsis-induced cognitive impairment in mouse hippocampus by enhancing autophagy. Cell Mol Neurobiol 37: 1195-1205, 2017.

69. Sarbassov DD, Ali SM and Sabatini DM: Growing roles for the mTOR pathway. Curr Opin Cell Biol 17: 596-603, 2005. 